OPEN ACCESS

Edited by:

Gaetano Santulli,

Columbia University, USA

Reviewed by:

Richard David Walton,

Université Bordeaux Segalen, France

Bozena Werner

Medical University of Warsaw, Poland

${ }^{*}$ Correspondence:

Gary Tse

gary.tse@doctors.org.uk

Bryan P. Yan

bryan.yan@cuhk.edu.hk

Specialty section:

This article was submitted to

Cardiac Electrophysiology,

a section of the journal

Frontiers in Physiology

Received: 07 June 2016 Accepted: 06 July 2016

Published: 21 July 2016

Citation:

Tse G, Yeo JM, Chan YW, Lai ETH and Yan BP (2016) What is the Arrhythmic

Substrate in Viral Myocarditis?

Insights from Clinical and Animal

Studies. Front. Physiol. 7:308

doi: 10.3389/fphys.2016.00308

\section{What Is the Arrhythmic Substrate in Viral Myocarditis? Insights from Clinical and Animal Studies}

\author{
Gary Tse ${ }^{1,2 *}$, Jie M. Yeo ${ }^{3}$, Yin Wah Chan ${ }^{4}$, Eric T. H. Lai ${ }^{1}$ and Bryan P. Yan ${ }^{2,5 *}$ \\ ${ }^{1} \mathrm{Li}$ Ka Shing Faculty of Medicine, School of Biomedical Sciences, University of Hong Kong, Hong Kong, China, ${ }^{2}$ Department \\ of Medicine and Therapeutics, The Chinese University of Hong Kong, Hong Kong, China, ${ }^{3}$ Faculty of Medicine, Imperial \\ College London, London, UK, ${ }^{4}$ Department of Psychology, School of Biological Sciences, University of Cambridge, \\ Cambridge, UK, ${ }^{5}$ Department of Epidemiology and Preventive Medicine, Monash University, Melbourne, VIC, Australia
}

Sudden cardiac death (SCD) remains an unsolved problem in the twenty-first century. It is often due to rapid onset, ventricular arrhythmias caused by a number of different clinical conditions. A proportion of SCD patients have identifiable diseases such as cardiomyopathies, but for others, the causes are unknown. Viral myocarditis is becoming increasingly recognized as a contributor to unexplained mortality, and is thought to be a major cause of SCD in the first two decades of life. Myocardial inflammation, ion channel dysfunction, electrophysiological, and structural remodeling may play important roles in generating life-threatening arrhythmias. The aim of this review article is to examine the electrophysiology of action potential conduction and repolarization and the mechanisms by which their derangements lead to triggered and reentrant arrhythmogenesis. By synthesizing experimental evidence from pre-clinical and clinical studies, a framework of how host (inflammation), and viral (altered cellular signaling) factors can induce ion electrophysiological and structural remodeling is illustrated. Current pharmacological options are mainly supportive, which may be accompanied by mechanical circulatory support. Heart transplantation is the only curative option in the worst case scenario. Future strategies for the management of viral myocarditis are discussed.

Keywords: viral myocarditis, cardiac arrhythmia, mouse model, viral-induced cardiomyopathy, conduction, repolarization

\section{INTRODUCTION}

Viral myocarditis is myocardial inflammation due to a viral infection. It is thought to be a major cause of sudden cardiac death (SCD) in the pediatric and adolescent population (Steinberger et al., 1996). Indeed, one study found that infants who suffered from SCD had mild fever and insomnia several days prior to their deaths, suggesting infection as a major contributor in this group (Gaaloul et al., 2016). At least 20 viruses have been implicated in myocarditis, but the commonest virus involved are Parvovirus B19 (PVB19), human herpes virus 6, adenovirus and coxsackievirus B3 (CVB3; Gaaloul et al., 2012). Table 1 summarizes the known virus strains, gene/protein targets, and estimated prevalence. Not all viral infections are the same: cardiotropic viruses are known to infect $>90 \%$ of the human population, yet only $1-5 \%$ of these will develop viral myocarditis as proven histologically (Andreoletti et al., 2009). 
TABLE 1 | The prevalence of different viruses was obtained from Kühl et al. (2005) and Andreoletti et al. (2009).

\begin{tabular}{|c|c|c|c|c|}
\hline Virus & Type & Host target & Estimated prevalence & References \\
\hline Adenovirus & dsDNA & $\begin{array}{l}\text { Common Coxsackievirus } \\
\text { B-adenovirus receptor }\end{array}$ & $8-23 \%$ & $\begin{array}{l}\text { Bergelson et al., 1997; Bowles et al., } \\
\text { 2003; Kühl et al., 2005; Andreoletti et al., } \\
2009\end{array}$ \\
\hline Coxsackievirus & ssRNA & $\begin{array}{l}\text { CD55, Common Coxsackievirus } \\
\text { B-adenovirus receptor }\end{array}$ & $\begin{array}{l}2 \text { to } 50 \% \text { (Up to } 46 \% \text { after } \\
\text { transplantation) }\end{array}$ & $\begin{array}{l}\text { Arbustini et al., 1992; Bergelson et al., } \\
\text { 1997; Martino et al., 1998; Bowles et al., } \\
\text { 2003; Andreoletti et al., } 2009\end{array}$ \\
\hline Cytomegalovirus & dsDNA & $\begin{array}{l}\text { Heparan Sulfate Proteoglycans, } \\
\text { PDGFR } \alpha, \text { EGFR, and integrin } \\
\text { heterodimers }\end{array}$ & $0.8-3 \%$ & Bowles et al., 2003; Chan et al., 2012 \\
\hline Echovirus & ssRNA & Human very late antigen 2 (VLA-2) & $10.5 \%$ & Hughes et al., 2003; Kühl et al., 2005 \\
\hline Enterovirus & ssRNA & $\begin{array}{l}\text { Enteroviral protease } 2 \text { A directly } \\
\text { cleaves dystrophin }\end{array}$ & $8-32.6 \%$ & $\begin{array}{l}\text { Badorff et al., 1999; Bowles et al., 2003; } \\
\text { Kühl et al., } 2005\end{array}$ \\
\hline Epstein-Barr virus & dsDNA & $\begin{array}{l}\text { Increased latent membrane protein } 1 \\
\text { is expressed in EBV latent cells }\end{array}$ & $0-6 \%$ & $\begin{array}{l}\text { Karjalainen et al., 1983; Bowles et al., } \\
\text { 2003; Chimenti et al., } 2004\end{array}$ \\
\hline Hepatitis B virus & dsDNA & Enters injured endothelium & $<1 \%$ & Reis et al., 2007; Rong et al., 2007 \\
\hline Hepatitis C virus & ssRNA & CD68 (monocytes and macrophages) & $2.9-3.8 \%$ & $\begin{array}{l}\text { Matsumori et al., 2000; Reis et al., 2007; } \\
\text { Matsumori, } 2012\end{array}$ \\
\hline $\begin{array}{l}\text { Herpes simplex } \\
\text { virus }\end{array}$ & dsDNA & & $<1 \%$ & Bowles et al., 2003 \\
\hline $\begin{array}{l}\text { Human herpes } \\
\text { virus } 6\end{array}$ & dsDNA & ?NK cells; infects endothelium & $8-10.5 \%$ & $\begin{array}{l}\text { Yoshikawa et al., 2001; Caruso et al., } \\
\text { 2002; Kühl et al., 2005; Andreoletti et al., } \\
2009\end{array}$ \\
\hline $\begin{array}{l}\text { Human } \\
\text { immunodeficiency } \\
\text { virus } 1 \text { and } 2\end{array}$ & ssRNA & Gp120 & Common in HIV positive patients & Shaboodien et al., 2013 \\
\hline Influenza virus & ssRNA & Ectopic trypsins & $\begin{array}{l}1.7-10 \% \text { (up to } 10 \% \text { patients in } \\
\text { influenza pandemics) }\end{array}$ & $\begin{array}{l}\text { Bowles et al., 2003; Rezkalla and Kloner, } \\
\text { 2010; Pan et al., 2011; Ukimura et al., } \\
2012\end{array}$ \\
\hline Mumps virus & ssRNA & & $\begin{array}{l}\text { Up to } 15 \% \text { of mumps cases before } \\
\text { introduction of vaccine (associated } \\
\text { with endocardial fibroelastosis) }\end{array}$ & Rosenberg, 1945; Arita et al., 1981 \\
\hline Parvovirus B19 & ssDNA & B19 receptor (erythrocyte P antigen) & $1-36.6 \%$ & $\begin{array}{l}\text { Porter et al., 1988; Bowles et al., 2003; } \\
\text { Kühl et al., 2005; Andreoletti et al., } 2009\end{array}$ \\
\hline Polio virus & ssRNA & & Up to $40 \%$ of cases of poliomyelitis & Laake, 1951 \\
\hline Rabies virus & ssRNA & Invasion of neural tissue or blood cells & $?$ & $\begin{array}{l}\text { Ross and Armentrout, 1962; Cheetham } \\
\text { et al., 1970; Venkat Raman et al., 1988; } \\
\text { Liao et al., } 2012\end{array}$ \\
\hline $\begin{array}{l}\text { Respiratory } \\
\text { syncytial virus }\end{array}$ & ssRNA & $?$ & $<1 \%$ & $\begin{array}{l}\text { Huang et al., 1998; Bowles et al., 2003; } \\
\text { Eisenhut, } 2006\end{array}$ \\
\hline Rubella virus & ssRNA & $?$ & $?$ & Ainger et al., 1966; Kriseman, 1984 \\
\hline $\begin{array}{l}\text { Vaccinia virus } \\
\text { (smallpox vaccine) }\end{array}$ & dsDNA & $?$ & $<1-9.5 \%$ & $\begin{array}{l}\text { Karjalainen et al., 1983; Casey et al., } \\
2005\end{array}$ \\
\hline Varicella virus & dsDNA & $?$ & $?$ & $\begin{array}{l}\text { Woolf et al., 1987; Rich and McErlean, } \\
\text { 1993; Alter et al., 2001; Biocic et al., } \\
\text { 2009; De et al., } 2011\end{array}$ \\
\hline
\end{tabular}

? - Information not available.

Patients can take a varied clinical course, from acute to chronic inflammation involving focal or diffuse areas of the myocardium (Fung et al., 2016). Figure 1 illustrates demonstrates the histology from a case of viral myocarditis due to PVB19, characterized by diffuse interstitial myocardial inflammatory infiltrate composed of CD68 positive macrophages, CD3 lymphocytes in an interstitial and perivascular distribution with minimal necrosis (Tavora et al., 2008). Some have insidious onset with limited inflammation, others undergo fulminant course with overwhelming inflammation or develop chronic heart failure from an autoimmune-mediated process (Heymans, 2006). There are some genetic predispositions, making some individuals more susceptible to viral myocarditis. For example, the commonest polymorphism for the KCNQ1 gene encoding for the slow inactivating $\mathrm{K}^{+}$channel in Asians, appears to be protective against viral-induced arrhythmias (Steinke et al., 2013). Not all viruses are the same: some viruses such as CVB3 and adenovirus serotype 5 can induce more severe viral myocarditis 


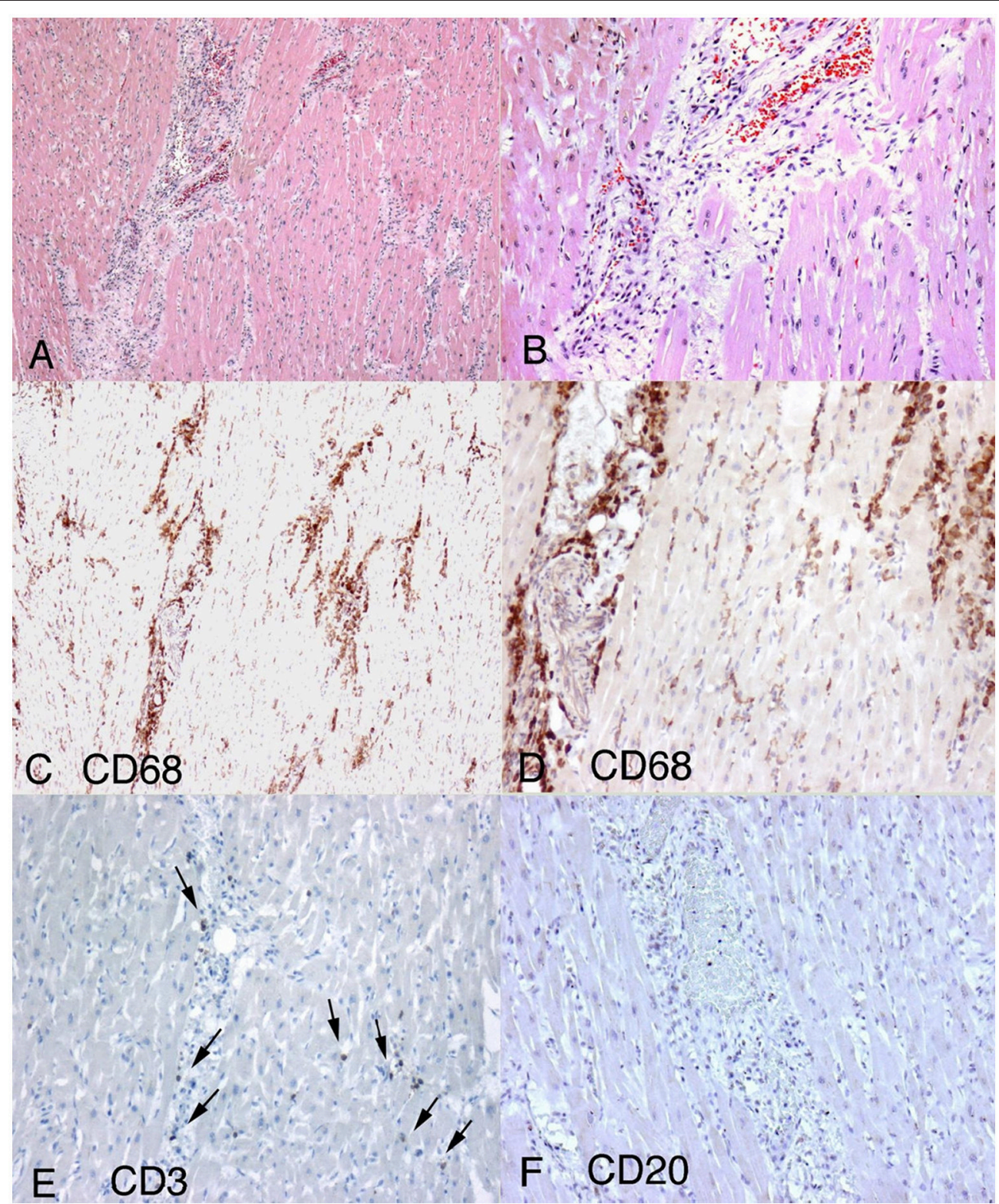

FIGURE 1 | Histopathological findings in parvoviral myocarditis. (A) Diffuse interstitial myocardial inflammatory infiltrate more prominent around interstitial capillaries and composed of macrophages and lymphocytes (20x). (B) Hematoxilin-eosin stain showing vasocentric inflammation (40x). (C,D) CD68 positive macrophages were the most abundant cells present. (C-10X D-20X; E) Rare CD3 positive lymphocytes. (F) Essentially negative CD20 immunohistochemical stain. Figure and figure legends reproduced from Tavora et al. (2008) with permission.

(Savon et al., 2008; Valdes et al., 2008). For the post-mortem of infants suffering from SCD, only a minority of cases showed features of myocardial inflammation (Gaaloul et al., 2012), suggesting contributing factors, such as signals initiated by the viruses leading to ion channel dysfunction or electrophysiological and structural remodeling, to arrhythmogenesis. Fundamentally, viruses must have some means of subverting the host's machinery for their replication to ensure their own survival. This can be achieved by using the host's signaling mechanisms or the mircroRNA (miRNA) system to target the host's messenger
RNAs for translational repression and degradation (Tomari and Zamore, 2005). The aim is to shut down the host's protein translation machinery and enhance viral pathogenicity or replication (Orom et al., 2008; Hemida et al., 2013; Tong et al., 2013; Ye et al., 2013). As we shall see later, altered cellular signaling, such as activation of kinases and enzymes, and upregulation of miRNAs, can lead to ion channel remodeling that can potentially reduce the threshold for arrhythmogenesis. Thus, the host's immune response or viral factor can induce electrophysiological or structural remodeling, resulting in action 
potential (AP) conduction or repolarization abnormalities to promote arrhythmogenesis (Figure 2; Tse and Yeo, 2015).

\section{ARRHYTHMOGENESIS CAN ARISE FROM AP CONDUCTION OR REPOLARIZATION ABNORMALITIES}

Mechanisms of arrhythmias can be divided into triggered activity and reentry (Figure 3; Tse, 2015; Tse et al., 2016m). Triggered activity arises from either early or delayed afterdepolarization phenomena (EADs and DADs), which are depolarization events occurring before the next AP. Normally the repolarization phase is determined by a balance of inward currents mediated by the $\mathrm{Na}^{+}-\mathrm{Ca}^{2+}$ exchanger $\left(I_{\mathrm{NCX}}\right)$ and L-type $\mathrm{Ca}^{2+}$ channels (LTCC, $\left.I_{\mathrm{Ca}, \mathrm{L}}\right)$, and outward currents mediated by a number of $\mathrm{K}^{+}$ channels $\left(I_{\mathrm{Kr}}, I_{\mathrm{Ks}}, I_{\mathrm{K} 1}, I_{\mathrm{K}, \mathrm{ATP}}\right.$; Nerbonne, 2000; Tse et al., 2016j). Prolongation in action potential duration (APD) can result in LTCC reactivation, typically during phase 2 or phase 3 of the AP, leading to EADs (January et al., 1988). By contrast, DADs can develop under conditions of intracellular $\mathrm{Ca}^{2+}$ overload (Priori and Corr, 1990). This involves spontaneous release of $\mathrm{Ca}^{2+}$ from the sarcoplasmic reticulum via the ryanodine receptors (RyRs) and subsequent activation of the $\mathrm{Na}^{+}-\mathrm{Ca}^{2+}$ exchanger (NCX). Both EADs and DADs can therefore result in membrane depolarization, and if these are of sufficient amplitude, triggered activity can be elicited.

Reentry involves re-activation of the myocardium that has recovered from refractoriness, and may involve an obstacle for the circus-type, or without an obstacle in phase 2 reentry (Tse et al., 2016d). Circus-type reentry requires three conditions: reduced conduction velocity $(\mathrm{CV})$ of the $\mathrm{AP}$ wave, so that the tissue ahead remains excitable, unidirectional conduction block to prevent APs traveling in opposite directions from extinguishing, and an obstacle (which can arise dynamically or be a fixed structural defect) around which the AP is able to circulate (Tse, 2015). Thus, a decrease in the wavelength of excitation $(\lambda)$ given by the product of $\mathrm{CV}$ and reduced effective refractory period (ERP), would predispose to reentry (Smeets et al., 1986; Vaidya et al., 1999; Osadchii, 2010, 2014; Tse et al., 2012, 2016e,f,g,k,o).

Of these parameters, $\mathrm{CV}$ of the APs traveling through the myocardium, traditionally described by the core conductor theory, depends on both passive and active membrane properties (Tse and Yeo, 2015; Tse et al., 2016d). Passive properties refer to the biophysical parameters of axial resistance $\left(r_{i}\right)$, extracellular resistance $\left(r_{0}\right)$ and membrane capacitance $\left(c_{m}\right)$. The existence of electrical communication pathways between successive cardiomyocytes was shown, mediated by gap junctions (Spray and Burt, 1990). Six connexin (Cx) subunits make up a connexon and two connexons make up a gap junction. Since the discovery of gap junctions, it has been assumed that their electrical coupling is the primary mechanism by which cardiac conduction occurs. However, this is in conflict with experiments in heterozygous $\mathrm{Cx} 43^{+/--}$mice, which showed $45-$ $50 \%$ reduction in $\mathrm{Cx} 43$ expression, but $\mathrm{CV}$ was either unaltered (Morley et al., 1999; Vaidya et al., 2001; van Rijen et al., 2004; Stein et al., 2009, 2011; George et al., 2015) or reduced by 2344\% (Guerrero et al., 1997; Thomas et al., 1998; Eloff et al., 2001). This suggests other mechanisms, such as ephaptic coupling, may have an important role in mediating cardiac conduction (Rhett and Gourdie, 2012; Lin and Keener, 2013, 2014; Rhett et al., 2013; Veeraraghavan et al., 2014a,b,c, 2015; George et al., 2015). This is clinically relevant because interstitial edema can increase

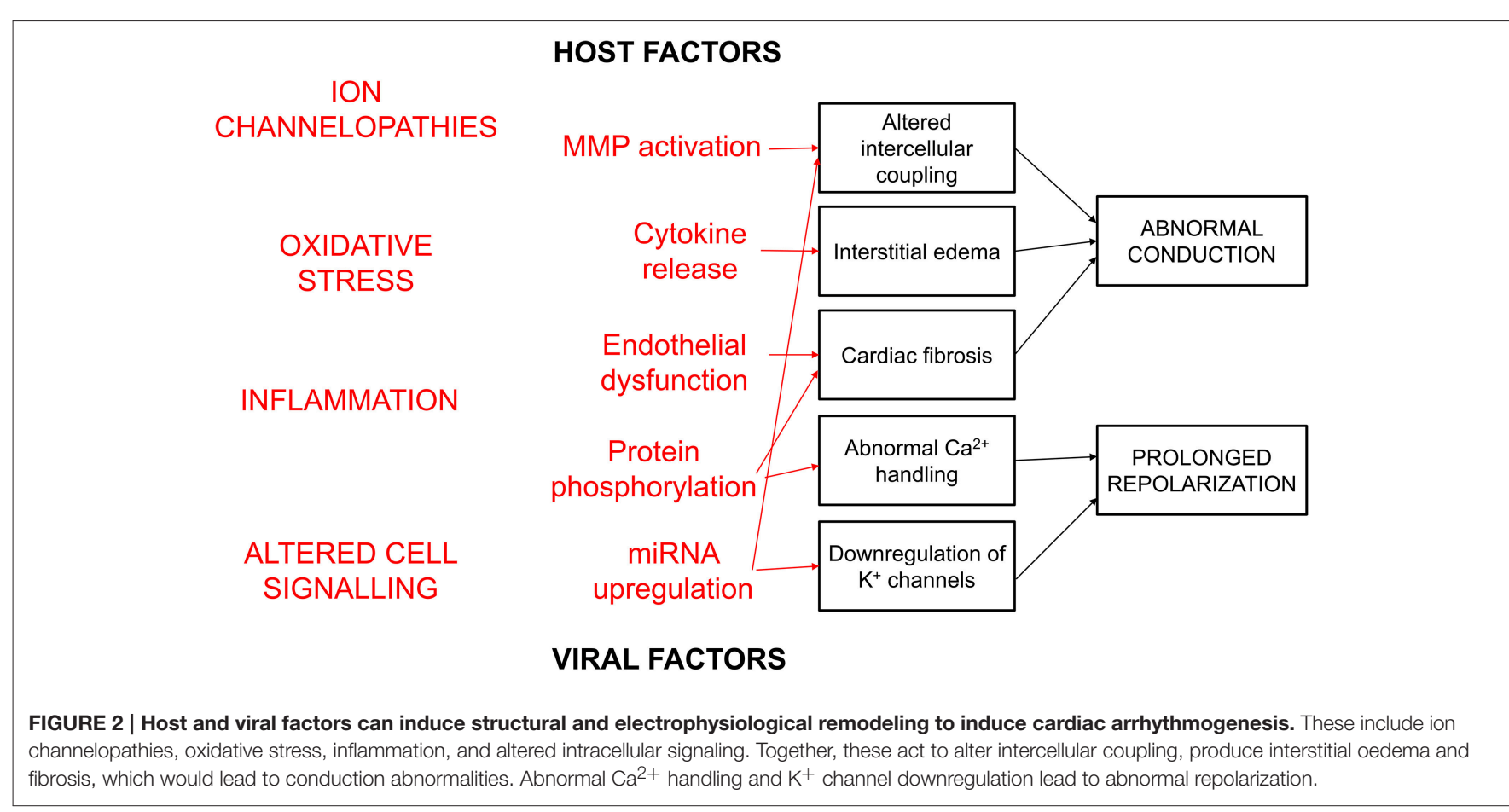




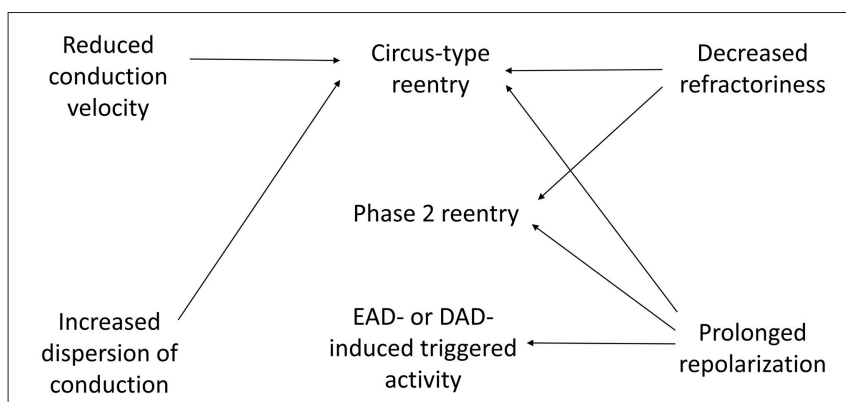

FIGURE 3 | Mechanisms of cardiac arrhythmias in viral myocarditis involves triggered activity and reentry. Prolonged repolarization leads to development of early afterdepolarizations (EADs), whereas abnormal $\mathrm{Ca}^{2+}$ handling produces delayed afterdepolarizations (DADs). EADs and DADs can elicit triggered activity. Reduced conduction velocity (CV), increased CV dispersion and decreased refractoriness can increase the likelihood of circus-type reentry. Prolonged repolarization and decreased refractoriness can predispose to phase 2 reentry.

extracellular volume, thereby reducing CV (Veeraraghavan et al., 2012).

Active properties refer to the voltage-gated conductance responsible for the AP upstroke, namely the $\mathrm{Na}^{+}$channels. The effective refractory period (ERP) is the time over which $\mathrm{Na}^{+}$channels are inactivated and cannot open again. They can be reactivated when the membrane potential is restored to the resting value. Thus, APD usually approximates ERP, i.e., a shorter repolarization time course usually leads to shorter ERP. When APDs are prolonged, sudden increase in heart rate can engage the steep portion of APD restitution curve, producing APD alternans, unidirectional conduction block, wave break and reentry (Hsieh et al., 2009, 2014, 2016; Tse et al., 2016m). Phase 2 reentry simply involves a difference in APD between two electrically connected regions, where conduction of the action potential dome from sites where it is maintained to sites where it is abolished can then result in an extrasystole (Shimizu et al., 2005). This is thought to underlie reentrant arrhythmogenesis in Brugada syndrome, and may be relevant in patients suffering from viral myocarditis with an unmasked Brugada phenotype.

\section{HOST-MEDIATED AND VIRAL-INDUCED INFLAMMATION AND CAN PROMOTE ARRHYTHMOGENESIS BY INDUCING ION CHANNEL ABNORMALITIES AND CARDIAC REMODELING}

All of the above factors governing conduction or repolarization can be affected by myocardial inflammation or changes induced by the viruses to promote arrhythmogenesis. Thus, in a rat model of immune-mediated myocarditis, increased oxidative stress and inflammation can increase the release of inflammatory cytokines such as tumor necrosis factor- $\alpha$ and interleukin-6, leading to $\mathrm{Ca}^{2+} /$ calmodulin Protein Kinase II (CaMKII) activation. This can phosphorylate the $\mathrm{Ca}^{2+}$ release channel, ryanodine receptor 2 (RyR2), to increase abnormal $\mathrm{Ca}^{2+}$ release from the sarcoplasmic reticulum (Tse et al., 2016n). Moreover, there is greater $\mathrm{Ca}^{2+}$ entry from the extracellular space (Tominaga et al., 1993). Both would lead to increased duration of $\mathrm{Ca}^{2+}$ transient, which would in turn prolong APD due to positive $\mathrm{Ca}_{\mathrm{i}}^{2+}$-APD coupling (Park et al., 2014a,b). This led to triggered activity, presumably via development of EADs, although DADs are also possible due to abnormal $\mathrm{Ca}^{2+}$ release. Regional differences in $\mathrm{Ca}^{2+}$ transients can also increase the heterogeneity in repolarization and produce arrhythmogenic APD alternans. In a rat model of autoimmune myocarditis, several ion channels mediating the fast transient outward $\left(I_{\mathrm{to}, \mathrm{f}}\right)$ and delayed rectifier $\left(I_{\mathrm{Kr}}\right)$ currents were downregulated (Saito et al., 2002; Wakisaka et al., 2004). This led to prolongations of both ERP and APD, the latter being responsible for EADs and triggered activity. Similar reduction of repolarizing currents leading to APD prolongation has also been observed in mice with autoimmune myocarditis (Tang et al., 2007). Inflammation can also promote changes in the extracellular matrix (ECM). Thus, ECM composition is regulated by matrix metalloproteinases (MMPs), which are normally inhibited by tissue inhibitors of matrix metalloproteinases (TIMPs; Pauschinger et al., 2004). MMP activation during acute myocarditis can tip the balance toward ECM remodeling, in turn causing fibrosis. This would reduce CV by disrupting cardiomyocyte-cardiomyocyte coupling or increasing fibroblastcardiomyocyte coupling, increasing $r_{i}$ and $C_{m}$, respectively (Tse and Yeo, 2015). Moreover, viral myocarditis predisposes to the development of dilated cardiomyopathy (DCM), which itself is arrhythmogenic. Interested readers are directed to this excellent article here for further discussion on the mechanisms by which myocardial infections by cardiotropic viruses lead to DCM and heart failure (Baksi et al., 2015).

Viruses can also alter the function or expression of ion channels or induce structural remodeling of the myocardium. CVB3 can increase the $I_{\mathrm{Ca}}$, leading to APD prolongation (Steinke et al., 2013). It also increases $I_{\mathrm{Kr}}$ and $I_{\mathrm{Ks}}$ initially but decreases them in the longer term, leading to APD shortening and prolongation, respectively. CVB3 can upregulate miR-1, which in turn disrupts cardiomyocyte-cardiomyocyte coupling by translational repression of the gene GJA1, which encodes for connexin-43 (Cx43; Xu et al., 2012). Together, these changes induced by $\mathrm{CVB} 3$ would produce $\mathrm{Ca}^{2+}$ overload and induce abnormalities in action potential repolarization and conduction, predisposing to both triggered activity and reentry. The cardiotropic PVB19 appears to target endothelial cells as opposed to cardiomyocytes (Bultmann et al., 2003). Since endothelial cells are found in the heart and can communicate with the adjacent cardiomyocytes, endothelial dysfunction may indeed be responsible for cardiac remodeling during inflammation. PVB19 a pro-apoptotic protein called viral protein NS1, which can activate caspase 3 , leading to the degradation of the $\mathrm{Na}^{+} / \mathrm{H}^{+}$ exchanger (Lupescu et al., 2009). Its B19 minor capsid protein VP1 has intrinsic phospholipase A2 activity, which can increase the activity of $\mathrm{Ca}^{2+}$ release-activated $\mathrm{Ca}^{2+}$ channel $\left(I_{\text {CRAC }}\right.$ ), which is normally responsible for capacitative, store-operated $\mathrm{Ca}^{2+}$ entry by increasing $I_{\mathrm{Ca}}$ (Lupescu et al., 2006). PLA2 activity of VP1 is thought to underlie downregulation of $\mathrm{Na}^{+} / \mathrm{K}^{+}$ATPase and a number of $\mathrm{K}^{+}$channels (mediating $I_{\mathrm{Kr}}$ and inward rectifying currents, $I_{\text {Kir }}$; Almilaji et al., 2013; Ahmed et al., 2014, 2015). 
Finally, there may be interaction between genetic predisposition of ion channel dysfunction and viral myocarditis (Salerno et al., 2011; Juhasz et al., 2014). In a case series, patients who suffered from viral myocarditis complicated by ventricular fibrillation showed electrocardiographic features of Brugada, early repolarization and short QT syndromes (Salerno et al., 2011). Interestingly, not only were ventricular arrhythmias observed during the acute phase of the myocarditis but persistent ECG changes were observed after the inflammation has subsided, suggesting underlying abnormalities in ion channel function, predisposing to arrhythmogenesis during myocarditis. Indeed, as pointed out by these authors (Salerno et al., 2011), this could be due to temperature-dependent alterations in ion channel function (Pasquié, 2005). This notion is consistent with previous observations that infants suffering from SCD had mild fever before their deaths (Gaaloul et al., 2016), which would suggest fever as a trigger of the arrhythmia (Pasquié, 2005). This is also in keeping with previous associations between exacerbation of a Brugada pattern and a febrile state (Patane and Marte, 2010; Patane et al., 2010).

\section{CURRENT MANAGEMENT OPTIONS AND FUTURE THERAPY}

Diagnosis of viral myocarditis can be difficult, and requires a series of investigations. Blood tests may reveal cardiac damage as reflected in raised troponins and high sensitive Creactive protein assays (Guo, 2008). Polymerase chain reaction (PCR) can be used to detect viral nucleic acid materials for confirming a specific viral infection. Electrocardiography is non-specific, but can reveal conduction block, ST segment elevation or $\mathrm{T}$ wave abnormalities. Ventricular tachycardia or fibrillation may be observed. Echocardiography is used to determine ventricular function and rule out non-viral causes of heart failure, and can distinguish between acute from fulminant myocarditis (Felker et al., 2000). Cardiac magnetic resonance imaging is excellent for characterizing structural abnormalities, such as areas of fibrosis by late gadolinium enhancement (Vassiliou et al., 2014; Tse et al., 2015a,b) It is highly valuable in the diagnosis of myocarditis because it can detect interstitial edema during acute inflammation and fibrosis from a reparative process (Babu-Narayan et al., 2007; Petryka et al., 2014; Baksi et al., 2015). Interstitial edema reflects increased extracellular fluid volume, which would reduce $\mathrm{CV}$ by an ephaptic mechanism. Traditionally, the confirmatory test for diagnosing viral myocarditis was endomyocardial biopsy, which can be guided by electro-anatomical mapping to reduce the likelihood of false negatives. The criteria is a value more than 14 leukocytes $/ \mathrm{mm}^{2}$ and a T-lymphocyte count of more than 7 cells $/ \mathrm{mm}^{2}$ (Basso et al., 2013). However, due to advances in CMR technology, the use of biopsy is now limited when giant cell myocarditis is suspected.

For arrhythmic risk stratification, using different indices based on ECG parameters have been used for congenital arrhythmic syndromes and heart failure (Tse, 2016a,b,c; Tse and Yan, 2016a,b), but not for viral myocarditis. CMR can be used for stratifying patients into low and high risk group for developing ventricular arrhythmogenesis by quantifying the amount of interstitial edema and fibrosis, which would guide monitoring and therapy (Strauss and Wu, 2009; Mavrogeni et al., 2013; Baksi et al., 2015; Kallianos et al., 2015; Neilan et al., 2015; Sanguineti et al., 2015; Anzini et al., 2016).

The major problem of viral myocarditis is the limited number of drugs available for modifying the course of the disease and preventing the arrhythmic complications (Kindermann et al., 2012). The current treatment is supportive, using medications such as angiotensin converting enzyme inhibitors, beta blockers and spironolactone. Anti-arrhythmic agents are used when ventricular arrhythmias are observed. Mechanical circulatory support is potentially life-saving by allowing an interval for the return of heart pumping function or providing a bridge to heart transplantation, which may be required in the worst case scenario (Duncan et al., 2001). Other suggested approaches are immunosuppression, immunoglobulin, immunoadsorption, and anti-viral treatment (Jensen and Marchant, 2016). However, immunosuppressive therapy should be limited to giant cell myocarditis and lymphocytic myocarditis. The use of intravenous immunoglobulin is not recommended currently. There is a pressing need for drug development, and novel therapeutic agents that can reduce viral entry into cardiomyocytes, and viral-induced or host-mediate myocardial inflammation, which would reduce the arrhythmic burden in this patient population.

The use of animal models has advanced our understanding of the mechanisms of arrhythmias and provide a platform for assessing the efficacy of pharmacological therapy (Chen et al., 2016; Choy et al., 2016; Tse et al., 2016a,b,c,h,i,l). Thus, pre-clinical mouse studies have demonstrated the efficacy of Chinese medicinal extracts such as QiHong and Qishaowuwei formula in suppressing viral attachment and penetration, which significantly ameliorated CVB3-induced myocardium necrosis (Song et al., 2007; Fengqin et al., 2010). The benefits of traditional Chinese medicines in viral myocarditis thus warrant further investigation. Other novel therapies include mutation of the viral genome to induce the expression of cytokines, such as interferon-gamma, which can modulate the immune responses and prevent inflammation (Henke et al., 2008). Modulation of ion channel function may be useful for anti-arrhythmic therapy. Triggered activity can be suppressed by reversing APD prolongation and/or $\mathrm{Ca}^{2+}$ overload. Thus, EADs can be inhibited the late $I_{\mathrm{Na}}$ (Belardinelli et al., 2013), whereas DADs could be abolished by blocking RyR2 (Savio-Galimberti and Knollmann, 2015) or NCX (Sipido et al., 2006). KATP channel openers such as mexiletine, with previously demonstrated cardioprotective effects during ischaemia, could suppress APD prolongation during acute myocarditis and may therefor protect against $\mathrm{Ca}^{2+}$ overload, DADs and spatial heterogeneities in APDs (Niwano et al., 2012).

In conclusion, viral myocarditis is an important cause of mortality especially in infants, adolescents and young adults, predisposing to life-threatening cardiac arrhythmias. Current drug options are inadequate and are mainly supportive. More efforts need to be devoted to the development 
of novel pharmacological agents that can prevent viral invasion of cardiac tissue as well as viral- or host-induced inflammation, and reducing arrhythmic complications of the myocarditis.

\section{AUTHOR CONTRIBUTIONS}

GT: Design of manuscript; drafted and critically revised the manuscript for important intellectual content; preparation

\section{REFERENCES}

Ahmed, M., Almilaji, A., Munoz, C., Elvira, B., Shumilina, E., Bock, C. T., et al. (2014). Down-regulation of $\mathrm{K}(+)$ channels by human parvovirus B19 capsid protein VP1. Biochem. Biophys. Res. Commun. 450, 1396-1401. doi: 10.1016/j.bbrc.2014.07.003

Ahmed, M., Elvira, B., Almilaji, A., Bock, C. T., Kandolf, R., and Lang, F. (2015). Down-regulation of inwardly rectifying Kir2.1 K+ channels by human parvovirus B19 capsid protein VP1. J. Membr. Biol. 248, 223-229. doi: 10.1007/s00232-014-9762-9

Ainger, L. E., Lawyer, N. G., and Fitch, C. W. (1966). Neonatal rubella myocarditis. Br. Heart J. 28, 691-697. doi: 10.1136/hrt.28.5.691

Almilaji, A., Szteyn, K., Fein, E., Pakladok, T., Munoz, C., Elvira, B., et al. (2013). Down-regulation of $\mathrm{Na} / \mathrm{K}+$ atpase activity by human parvovirus B19 capsid protein VP1. Cell. Physiol. Biochem. 31, 638-648. doi: 10.1159/000 350083

Alter, P., Grimm, W., and Maisch, B. (2001). Varicella myocarditis in an adult. Heart 85:e2. doi: 10.1136/heart.85.1.e2

Andreoletti, L., Leveque, N., Boulagnon, C., Brasselet, C., and Fornes, P. (2009). Viral causes of human myocarditis. Arch. Cardiovasc. Dis. 102, 559-568. doi: 10.1016/j.acvd.2009.04.010

Anzini, M., Merlo, M., Artico, J., and Sinagra, G. (2016). Arrhythmic risk prediction of acute myocarditis presenting with life-threatening ventricular tachyarrhythmias. Int. J. Cardiol. 212, 169-170. doi: 10.1016/j.ijcard.2016.03.020

Arbustini, E., Grasso, M., Diegoli, M., Percivalle, E., Grossi, P., Bramerio, M., et al. (1992). Histopathologic and molecular profile of human cytomegalovirus infections in patients with heart transplants. Am. J. Clin. Pathol. 98, 205-213. doi: 10.1093/ajcp/98.2.205

Arita, M., Ueno, Y., and Masuyama, Y. (1981). Complete heart block in mumps myocarditis. Br. Heart J. 46, 342-344. doi: 10.1136/hrt.46.3.342

Babu-Narayan, S. V., McCarthy, K. P., Ho, S. Y., Magee, A. G., Kilner, P. J., and Sheppard, M. N. (2007). Myocarditis and sudden cardiac death in the young: extensive fibrosis suggested by cardiovascular magnetic resonance in vivo and confirmed post mortem. Circulation 116, e122-e125. doi: 10.1161/CIRCULATIONAHA.107.693085

Badorff, C., Lee, G. H., Lamphear, B. J., Martone, M. E., Campbell, K. P., Rhoads, R. E., et al. (1999). Enteroviral protease 2A cleaves dystrophin: evidence of cytoskeletal disruption in an acquired cardiomyopathy. Nat. Med. 5, 320-326. doi: $10.1038 / 6543$

Baksi, A. J., Kanaganayagam, G. S., and Prasad, S. K. (2015). Arrhythmias in viral myocarditis and pericarditis. Card. Electrophysiol. Clin. 7, 269-281. doi: 10.1016/j.ccep.2015.03.009

Basso, C., Calabrese, F., Angelini, A., Carturan, E., and Thiene, G. (2013). Classification and histological, immunohistochemical, and molecular diagnosis of inflammatory myocardial disease. Heart Fail. Rev. 18, 673-681. doi: 10.1007/s10741-012-9355-6

Belardinelli, L., Liu, G., Smith-Maxwell, C., Wang, W. Q., El-Bizri, N., Hirakawa, R., et al. (2013). A novel, potent, and selective inhibitor of cardiac late sodium current suppresses experimental arrhythmias. J. Pharmacol. Exp. Ther. 344, 23-32. doi: 10.1124/jpet.112.198887

Bergelson, J. M., Cunningham, J. A., Droguett, G., Kurt-Jones, E. A., Krithivas, A., Hong, J. S., et al. (1997). Isolation of a common receptor for of figures. JY: Drafted and critically revised the manuscript for important intellectual content. EL: Drafted and critically revised the manuscript for important intellectual content. BY: Interpreted primary research papers; critically revised the manuscript for important intellectual content.

\section{ACKNOWLEDGMENTS}

GT was awarded a BBSRC Doctoral Training Award and thanks for the Croucher Foundation for its generous support.
Coxsackie B viruses and adenoviruses 2 and 5. Science 275, 1320-1323. doi: $10.1126 /$ science. 275.5304 .1320

Biocic, S., Durasevic, Z., Starcevic, B., and Udovicic, M. (2009). [Varicella zoster myopericarditis in an immunocompetent adult]. Acta Med. Croatica 63, 325-327.

Bowles, N. E., Ni, J., Kearney, D. L., Pauschinger, M., Schultheiss, H. P., McCarthy, R., et al. (2003). Detection of viruses in myocardial tissues by polymerase chain reaction. Evidence of adenovirus as a common cause of myocarditis in children and adults. J. Am. Coll. Cardiol. 42, 466-472. doi: 10.1016/s07351097(03)00648-x

Bultmann, B. D., Klingel, K., Sotlar, K., Bock, C. T., Baba, H. A., Sauter, M., et al. (2003). Fatal parvovirus B19-associated myocarditis clinically mimicking ischemic heart disease: an endothelial cell-mediated disease. Hum. Pathol. 34, 92-95. doi: 10.1053/hupa.2003.48

Caruso, A., Rotola, A., Comar, M., Favilli, F., Galvan, M., Tosetti, M., et al. (2002). HHV-6 infects human aortic and heart microvascular endothelial cells, increasing their ability to secrete proinflammatory chemokines. J. Med. Virol. 67, 528-533. doi: 10.1002/jmv.10133

Casey, C. G., Iskander, J. K., Roper, M. H., Mast, E. E., Wen, X. J., Torok, T. J., et al. (2005). Adverse events associated with smallpox vaccination in the United States, January-October 2003. JAMA 294, 2734-2743. doi: 10.1001/jama.294.21.2734

Chan, G., Nogalski, M. T., Stevenson, E. V., and Yurochko, A. D. (2012). Human cytomegalovirus induction of a unique signalsome during viral entry into monocytes mediates distinct functional changes: a strategy for viral dissemination. J. Leukoc. Biol. 92, 743-752. doi: 10.1189/jlb.0112040

Cheetham, H. D., Hart, J., Coghill, N. F., and Fox, B. (1970). Rabies with myocarditis. Lancet 295, 921-922. doi: 10.1016/S0140-6736(70)91048-2

Chen, Z., Sun, B., Tse, G., Jiang, J., and Xu, W. (2016). Reversibility of both sinus node dysfunction and reduced HCN4 mRNA expression level in an atrial tachycardia pacing model of tachycardia-bradycardia syndrome in rabbit hearts. Int. J. Clin. Exp. Pathol.

Chimenti, C., Russo, A., Pieroni, M., Calabrese, F., Verardo, R., Thiene, G., et al. (2004). Intramyocyte detection of Epstein-Barr virus genome by laser capture microdissection in patients with inflammatory cardiomyopathy. Circulation 110, 3534-3539. doi: 10.1161/01.CIR.0000148823.08092.0E

Choy, L., Yeo, J. M., Tse, V., Chan, S. P., and Tse, G. (2016). Cardiac disease and arrhythmogenesis: mechanistic insights from mouse models. Int. J. Cardiol. Heart. Vasc. 12, 1-10. doi: 10.1016/j.ijcha.2016.05.005

De, A., Myridakis, D., Kerrigan, M., and Kiblawi, F. (2011). Varicella myopericarditis mimicking myocardial infarction in a 17 -year-old boy. Tex. Heart Inst. J. 38, 288-290.

Duncan, B. W., Bohn, D. J., Atz, A. M., French, J. W., Laussen, P. C., and Wessel, D. L. (2001). Mechanical circulatory support for the treatment of children with acute fulminant myocarditis. J. Thorac. Cardiovasc. Surg. 122, 440-448. doi: $10.1067 / \mathrm{mtc} .2001 .115243$

Eisenhut, M. (2006). Extrapulmonary manifestations of severe respiratory syncytial virus infection - a systematic review. Crit. Care 10, R107. doi: $10.1186 / \mathrm{cc} 4984$

Eloff, B. C., Lerner, D. L., Yamada, K. A., Schuessler, R. B., Saffitz, J. E., and Rosenbaum, D. S. (2001). High resolution optical mapping reveals conduction slowing in connexin43 deficient mice. Cardiovasc. Res. 51, 681-690. doi: 10.1016/S0008-6363(01)00341-8 
Felker, G. M., Boehmer, J. P., Hruban, R. H., Hutchins, G. M., Kasper, E. K., Baughman, K. L., et al. (2000). Echocardiographic findings in fulminant and acute myocarditis. J. Am. Coll. Cardiol. 36, 227-232. doi: 10.1016/S07351097(00)00690-2

Fengqin, L., Yulin, W., Xiaoxin, Z., Youpeng, J., Yan, C., Qing-qing, W., et al. (2010). The heart-protective mechanism of Qishaowuwei formula on murine viral myocarditis induced by CVB3. J. Ethnopharmacol. 127, 221-228. doi: 10.1016/j.jep.2009.11.017

Fung, G., Luo, H., Qiu, Y., Yang, D., and McManus, B. (2016). Myocarditis. Circ. Res. 118, 496-514. doi: 10.1161/CIRCRESAHA.115.306573

Gaaloul, I., Riabi, S., Evans, M., Hunter, T., Huber, S., and Aouni, M. (2016). Postmortem diagnosis of infectious heart diseases: a mystifying cause of Sudden Infant Death. Forensic Sci. Int. 262, 166-172. doi: 10.1016/j.forsciint.2016.03.002

Gaaloul, I., Riabi, S., Harrath, R., Evans, M., Salem, N. H., Mlayeh, S., et al. (2012). Sudden unexpected death related to enterovirus myocarditis: histopathology, immunohistochemistry and molecular pathology diagnosis at post-mortem. BMC Infect. Dis. 12:212. doi: 10.1186/1471-2334-12-212

George, S. A., Sciuto, K. J., Lin, J., Salama, M. E., Keener, J. P., Gourdie, R. G., et al. (2015). Extracellular sodium and potassium levels modulate cardiac conduction in mice heterozygous null for the Connexin43 gene. Pflugers Arch. 467, 2287-2297. doi: 10.1007/s00424-015-1698-0

Guerrero, P. A., Schuessler, R. B., Davis, L. M., Beyer, E. C., Johnson, C. M., Yamada, K. A., et al. (1997). Slow ventricular conduction in mice heterozygous for a connexin43 null mutation. J. Clin. Invest. 99, 1991-1998. doi: 10.1172/JCI119367

Guo, J. G. (2008). [Detection of cardiac troponin and high-sensitivity C reactive protein in children with viral myocarditis]. Nan Fang Yi Ke Da Xue Xue Bao 28, 1076-1077. doi: 10.1007/s00246-010-9814-6

Hemida, M. G., Ye, X., Zhang, H. M., Hanson, P. J., Liu, Z., McManus, B. M., et al. (2013). MicroRNA-203 enhances coxsackievirus B3 replication through targeting zinc finger protein-148. Cell. Mol. Life Sci. 70, 277-291. doi: 10.1007/s00018-012-1104-4

Henke, A., Jarasch, N., Martin, U., Wegert, J., Wildner, A., Zell, R., et al. (2008). Recombinant coxsackievirus vectors for prevention and therapy of virus-induced heart disease. Int. J. Med. Microbiol. 298, 127-134. doi: 10.1016/j.ijmm.2007.08.010

Heymans, S. (2006). Inflammation and cardiac remodeling during viral myocarditis. Ernst Schering Res. Found. Workshop 55, 197-218. doi: 10.1007/3540-30822-9_12

Hsieh, Y. C., Lin, J. C., Hung, C. Y., Li, C. H., Lin, S. F., Yeh, H. I., et al. (2016). Gap junction modifier rotigaptide decreases the susceptibility to ventricular arrhythmia by enhancing conduction velocity and suppressing discordant alternans during therapeutic hypothermia in isolated rabbit hearts. Heart Rhythm. 13, 251-261. doi: 10.1016/j.hrthm.2015.07.023

Hsieh, Y. C., Lin, S. F., Huang, J. L., Hung, C. Y., Lin, J. C., Liao, Y. C., et al. (2014). Moderate hypothermia (33C) decreases the susceptibility to pacinginduced ventricular fibrillation compared with severe hypothermia (30C) by attenuating spatially discordant alternans in isolated rabbit hearts. Acta Cardiol Sin. 30, 455-465.

Hsieh, Y. C., Lin, S. F., Lin, T. C., Ting, C. T., and Wu, T. J. (2009). Therapeutic hypothermia (30 degrees $\mathrm{C}$ ) enhances arrhythmogenic substrates, including spatially discordant alternans, and facilitates pacing-induced ventricular fibrillation in isolated rabbit hearts. Circ. J. 73, 2214-2222. doi: 10.1253/circj.CJ09-0432

Huang, M., Bigos, D., and Levine, M. (1998). Ventricular arrhythmia associated with respiratory syncytial viral infection. Pediatr. Cardiol. 19, 498-500. doi: 10.1007/s002469900369

Hughes, S. A., Thaker, H. M., and Racaniello, V. R. (2003). Transgenic mouse model for echovirus myocarditis and paralysis. Proc. Natl. Acad. Sci. U.S.A. 100, 15906-15911. doi: 10.1073/pnas.2535934100

January, C. T., Riddle, J. M., and Salata, J. J. (1988). A model for early afterdepolarizations: induction with the Ca2+ channel agonist Bay K 8644 . Circ. Res. 62, 563-571. doi: 10.1161/01.RES.62.3.563

Jensen, L. D., and Marchant, D. J. (2016). Emerging pharmacologic targets and treatments for myocarditis. Pharmacol. Ther. 161, 40-51. doi: 10.1016/j.pharmthera.2016.03.006
Juhasz, Z., Tiszlavicz, L., Kele, B., Terhes, G., Deak, J., Rudas, L., et al. (2014). Sudden cardiac death from parvovirus B19 myocarditis in a young man with Brugada syndrome. J. Forensic Leg. Med. 25, 8-13. doi: 10.1016/j.jflm.2014.04.018

Kallianos, K., Moraes, G. L., and Ordovas, K. G. (2015). Prognostic role of MR imaging in nonischemic myocardial disease. Magn. Reson. Imaging Clin. N. Am. 23, 89-94. doi: 10.1016/j.mric.2014.09.004

Karjalainen, J., Heikkila, J., Nieminen, M. S., Jalanko, H., Kleemola, M., Lapinleimu, K., et al. (1983). Etiology of mild acute infectious myocarditis. relation to clinical features. Acta Med. Scand. 213, 65-73. doi: 10.1111/j.09546820.1983.tb03692.x

Kindermann, I., Barth, C., Mahfoud, F., Ukena, C., Lenski, M., Yilmaz, A., et al. (2012). Update on Myocarditis. J. Am. Coll. Cardiol. 59, 779-792. doi: 10.1016/j.jacc.2011.09.074

Kriseman, T. (1984). Rubella myocarditis in a 9-year-old patient. Clin. Pediatr. 23, 240-241. doi: 10.1177/000992288402300413

Kühl, U., Pauschinger, M., Noutsias, M., Seeberg, B., Bock, T., Lassner, D., et al. (2005). High prevalence of viral genomes and multiple viral infections in the myocardium of adults with "idiopathic" left ventricular dysfunction. Circulation 111, 887-893. doi: 10.1161/01.CIR.0000155616.07901.35

Laake, H. (1951). Myocarditis in Poliomyelitis. Acta Med. Scand. 140, 159-169. doi: 10.1111/j.0954-6820.1951.tb10168.x

Liao, P.-H., Hsu, Y.-H., Yang, H.-H., Wang, M.-H., and Chen, L.-K. (2012). Involvement of extraneural tissues and upregulation of inducible nitric oxide synthase after experimental infection with rabies virus in BALB/c mice and LEW/SsN rats. Pathol. Int. 62, 619-627. doi: 10.1111/j.1440-1827.2012.02846.x

Lin, J., and Keener, J. P. (2013). Ephaptic coupling in cardiac myocytes. IEEE Trans. Biomed. Eng. 60, 576-582. doi: 10.1109/TBME.2012.2226720

Lin, J., and Keener, J. P. (2014). Microdomain effects on transverse cardiac propagation. Biophys. J. 106, 925-931. doi: 10.1016/j.bpj.2013.11.1117

Lupescu, A., Bock, C. T., Lang, P. A., Aberle, S., Kaiser, H., Kandolf, R., et al. (2006). Phospholipase A2 Activity-Dependent Stimulation of $\mathrm{Ca}(2+)$ Entry by Human Parvovirus B19 Capsid Protein VP1. J. Virol. 80, 11370-11380. doi: 10.1128/JVI.01041-06

Lupescu, A., Geiger, C., Zahir, N., Aberle, S., Lang, P. A., Kramer, S., et al. (2009). Inhibition of $\mathrm{Na}^{+} / \mathrm{H}^{+}$exchanger activity by parvovirus B19 protein NS1. Cell. Physiol. Biochem. 23, 211-220. doi: 10.1159/000204110

Martino, T. A., Petric, M., Brown, M., Aitken, K., Gauntt, C. J., Richardson, C. D., et al. (1998). Cardiovirulent coxsackieviruses and the decay-accelerating factor (CD55) receptor. Virology 244, 302-314. doi: 10.1006/viro.1998.9122

Matsumori, A. (2012). Myocarditis: past, present and future. Kitasato Med. J. 42, $3-7$.

Matsumori, A., Yutani, C., Ikeda, Y., Kawai, S., and Sasayama, S. (2000). Hepatitis $\mathrm{C}$ virus from the hearts of patients with myocarditis and cardiomyopathy. Lab. Invest. 80, 1137-1142. doi: 10.1038/labinvest.3780120

Mavrogeni, S., Petrou, E., Kolovou, G., Theodorakis, G., and Iliodromitis, E. (2013). Prediction of ventricular arrhythmias using cardiovascular magnetic resonance. Eur. Heart J. Cardiovasc. Imaging 14, 518-525. doi: 10.1093/ehjci/jes302

Morley, G. E., Vaidya, D., Samie, F. H., Lo, C., Delmar, M., and Jalife, J. (1999). Characterization of conduction in the ventricles of normal and heterozygous Cx43 knockout mice using optical mapping. J. Cardiovasc. Electrophysiol. 10, 1361-1375. doi: 10.1111/j.1540-8167.1999.tb00192.x

Neilan, T. G., Farhad, H., Mayrhofer, T., Shah, R. V., Dodson, J. A., Abbasi, S. A., et al. (2015). Late gadolinium enhancement among survivors of sudden cardiac arrest. JACC Cardiovasc. Imaging 8, 414-423. doi: 10.1016/j.jcmg.2014.11.017

Nerbonne, J. M. (2000). Molecular basis of functional voltage-gated K+ channel diversity in the mammalian myocardium. J. Physiol. 525, 285-298. doi: 10.1111/j.1469-7793.2000.t01-1-00285.x

Niwano, S., Hirasawa, S., Niwano, H., Sasaki, S., Masuda, R., Sato, K., et al. (2012). Cardioprotective effects of sarcolemmal and mitochondrial K-ATP channel openers in an experimental model of autoimmune myocarditis. Role of the reduction in calcium overload during acute heart failure. Int. Heart J. 53, 139-145. doi: 10.1536/ihj.53.139

Orom, U. A., Nielsen, F. C., and Lund, A. H. (2008). MicroRNA-10a binds the $5^{\prime}$ UTR of ribosomal protein mRNAs and enhances their translation. Mol. Cell 30, 460-471. doi: 10.1016/j.molcel.2008.05.001 
Osadchii, O. E. (2010). Mechanisms of hypokalemia-induced ventricular arrhythmogenicity. Fundam. Clin. Pharmacol. 24, 547-559. doi: $10.1111 /$ j.1472-8206.2010.00835.x

Osadchii, O. E. (2014). Impact of hypokalemia on electromechanical window, excitation wavelength and repolarization gradients in guinea-pig and rabbit hearts. PLoS ONE 9:e105599. doi: 10.1371/journal.pone.0105599

Pan, H. Y., Yamada, H., Chida, J., Wang, S., Yano, M., Yao, M., et al. (2011). Up-regulation of ectopic trypsins in the myocardium by influenza A virus infection triggers acute myocarditis. Cardiovasc. Res. 89, 595-603. doi: $10.1093 / \mathrm{cvr} / \mathrm{cvq} 358$

Park, H., Park, H., Lee, D., Oh, S., Lim, J., Hwang, H. J., et al. (2014a). Increased phosphorylation of $\mathrm{Ca}(2+)$ handling proteins as a proarrhythmic mechanism in myocarditis. Circ. J. 78, 2292-2301. doi: 10.1253/circj.CJ14-0277

Park, H., Park, H., Lim, J., Oh, S., Park, S., Pak, H. M., et al. (2014b). Arrhythmogenic mechanisms of autoimmune myocarditis associated with inflammation and $\mathrm{Ca}_{2}+/$ calmodulin-dependent protein kinase II activation. Int. J. Arrhythm. 15, 4-16.

Pasquié, J. L. (2005). May Fever Trigger Ventricular Fibrillation? Indian Pacing Electrophysiol. J. 5, 139-145.

Patane, S., and Marte, F. (2010). Revelation of Brugada electrocardiographic pattern during a febrile state associated with acute myocardial infarction. Int. J. Cardiol. 144, e1-e4. doi: 10.1016/j.ijcard.2008.12.037

Patane, S., Marte, F., La Rosa, F. C., Albanese, A., La Rocca, R., and Villari, S. A. (2010). Revelation of Brugada electrocardiographic pattern during a febrile state. Int. J. Cardiol. 140, e19-e21. doi: 10.1016/j.ijcard.2008. 11.069

Pauschinger, M., Chandrasekharan, K., and Schultheiss, H. P. (2004). Myocardial remodeling in viral heart disease: possible interactions between inflammatory mediators and MMP-TIMP system. Heart Fail. Rev. 9, 21-31. doi: 10.1023/B:HREV.0000011391.81676.3c

Petryka, J., Baksi, A. J., Prasad, S. K., Pennell, D. J., and Kilner, P. J. (2014). Prevalence of inferobasal myocardial crypts among patients referred for cardiovascular magnetic resonance. Circ. Cardiovasc. Imaging 7, 259-264. doi: 10.1161/CIRCIMAGING.113.001241

Porter, H. J., Quantrill, A. M., and Fleming, K. A. (1988). B19 parvovirus infection of myocardial cells. Lancet 1, 535-536. doi: 10.1016/S0140-6736(88)91332-3

Priori, S. G., and Corr, P. B. (1990). Mechanisms underlying early and delayed afterdepolarizations induced by catecholamines. Am. J. Physiol. 258, H1796H1805.

Reis, F. J., Viana, M., Oliveira, M., Sousa, T. A., and Parana, R. (2007). Prevalence of hepatitis C and B virus infection in patients with idiopathic dilated cardiomyopathy in Brazil: a pilot study. Braz. J. Infect. Dis. 11, 318-321. doi: $10.1590 /$ S1413-86702007000300004

Rezkalla, S. H., and Kloner, R. A. (2010). Influenza-related viral myocarditis. WMJ 109, 209-213.

Rhett, J. M., and Gourdie, R. G. (2012). The perinexus: a new feature of Cx43 gap junction organization. Heart Rhythm 9, 619-623. doi: 10.1016/j.hrthm.2011.10.003

Rhett, J. M., Veeraraghavan, R., Poelzing, S., and Gourdie, R. G. (2013). The perinexus: sign-post on the path to a new model of cardiac conduction? Trends Cardiovasc. Med. 23, 222-228. doi: 10.1016/j.tcm.2012.12.005

Rich, R., and McErlean, M. (1993). Complete heart block in a child with varicella. Am. J. Emerg. Med. 11, 602-605. doi: 10.1016/0735-6757(93)90011-Y

Rong, Q., Huang, J., Su, E., Li, J., Li, J., Zhang, L., et al. (2007). Infection of hepatitis $B$ virus in extrahepatic endothelial tissues mediated by endothelial progenitor cells. Virol. J. 4, 1-14. doi: 10.1186/1743-422X-4-36

Rosenberg, D. H. (1945). Electrocardiographic Changes in Epidemic Parotitis (Mumps). Exp. Biol. Med. 58, 9-11. doi: 10.3181/00379727-58-14819

Ross, E., and Armentrout, S. A. (1962). Myocarditis Associated with Rabies. N. Engl. J. Med. 266, 1087-1089. doi: 10.1056/NEJM196205242662105

Saito, J., Niwano, S., Niwano, H., Inomata, T., Yumoto, Y., Ikeda, K., et al. (2002). Electrical remodeling of the ventricular myocardium in myocarditis: studies of rat experimental autoimmune myocarditis. Circ. J. 66, 97-103. doi: $10.1253 /$ circj.66.97

Salerno, F., Girerd, N., Chalabreysse, L., Billaud, G., Lina, B., and Chevalier, P. (2011). Myocarditis and cardiac channelopathies: a deadly association? Int. J. Cardiol. 147, 468-470. doi: 10.1016/j.ijcard.2011.01.019
Sanguineti, F., Garot, P., Mana, M., O’H-Ici, D., Hovasse, T., Unterseeh, T., et al. (2015). Cardiovascular magnetic resonance predictors of clinical outcome in patients with suspected acute myocarditis. J. Cardiovasc. Magn. Reson. 17, 78. doi: 10.1186/s12968-015-0185-2

Savio-Galimberti, E., and Knollmann, B. C. (2015). Channel activity of cardiac ryanodine receptors (RyR2) determines potency and efficacy of flecainide and r-propafenone against arrhythmogenic calcium waves in ventricular cardiomyocytes. PLOS ONE 10:e0131179. doi: 10.1371/journal.pone.01 31179

Savon, C., Acosta, B., Valdes, O., Goyenechea, A., Gonzalez, G., Pinon, A., et al. (2008). A myocarditis outbreak with fatal cases associated with adenovirus subgenera C among children from Havana City in 2005. J. Clin. Virol. 43, 152-157. doi: 10.1016/j.jcv.2008.05.012

Shaboodien, G., Maske, C., Wainwright, H., Smuts, H., Ntsekhe, M., Commerford, P. J., et al. (2013). Prevalence of myocarditis and cardiotropic virus infection in Africans with HIV-associated cardiomyopathy, idiopathic dilated cardiomyopathy and heart transplant recipients: a pilot study: cardiovascular topic. Cardiovasc. J. Afr. 24, 218-223. doi: 10.5830/CVJA2013-039

Shimizu, W., Aiba, T., and Kamakura, S. (2005). Mechanisms of disease: current understanding and future challenges in Brugada syndrome. Nat. Clin. Pract. Cardiovasc. Med. 2, 408-414. doi: 10.1038/ncpcardio0268

Sipido, K. R., Varro, A., and Eisner, D. (2006). Sodium calcium exchange as a target for antiarrhythmic therapy. Handb. Exp. Pharmacol. 171, 159-199. doi: 10.1007/3-540-29715-4_6

Smeets, J. L., Allessie, M. A., Lammers, W. J., Bonke, F. I., and Hollen, J. (1986). The wavelength of the cardiac impulse and reentrant arrhythmias in isolated rabbit atrium. The role of heart rate, autonomic transmitters, temperature, and potassium. Circ. Res. 58, 96-108. doi: 10.1161/01.RES.58.1.96

Song, X., Liu, Z., Wang, H., Xin, Y., Wang, X., Chen, J., et al. (2007). QiHong prevents death in coxsackievirus B3 induced murine myocarditis through inhibition of virus attachment and penetration. Exp. Biol. Med. (Maywood) 232, 1441-1448. doi: 10.3181/0704-RM-110

Spray, D. C., and Burt, J. M. (1990). Structure-activity relationships of the cardiac gap junction channel. Am. J. Physiol. 258, C195-C205.

Stein, M., van Veen, T. A., Hauer, R. N., de Bakker, J. M., and van Rijen, H. V. (2011). A 50\% reduction of excitability but not of intercellular coupling affects conduction velocity restitution and activation delay in the mouse heart. PLoS ONE 6:e20310. doi: 10.1371/journal.pone.0020310

Stein, M., van Veen, T. A., Remme, C. A., Boulaksil, M., Noorman, M., van Stuijvenberg, L., et al. (2009). Combined reduction of intercellular coupling and membrane excitability differentially affects transverse and longitudinal cardiac conduction. Cardiovasc. Res. 83, 52-60. doi: 10.1093/cvr/cvp124

Steinberger, J., Lucas, R. V. Jr., Edwards, J. E., and Titus, J. L. (1996). Causes of sudden unexpected cardiac death in the first two decades of life. Am. J. Cardiol. 77, 992-995. doi: 10.1016/S0002-9149(96)00035-5

Steinke, K., Sachse, F., Ettischer, N., Strutz-Seebohm, N., Henrion, U., Rohrbeck, M., et al. (2013). Coxsackievirus B3 modulates cardiac ion channels. FASEB J. 27, 4108-4121. doi: 10.1096/fj.13-230193

Strauss, D. G., and Wu, K. C. (2009). Imaging myocardial scar and arrhythmic risk prediction-a role for the electrocardiogram? J. Electrocardiol. 42, 138 e131-138 e138. doi: 10.1016/j.jelectrocard.2008.12.010

Tang, Q., Huang, J., Qian, H., Chen, L., Wang, T., Wang, H., et al. (2007). Antiarrhythmic effect of atorvastatin on autoimmune myocarditis is mediated by improving myocardial repolarization. Life Sci. 80, 601-608. doi: 10.1016/j.lfs.2006.11.045

Tavora, F., Gonzalez-Cuyar, L. F., Dalal, J. S., O’Malley, M. T., Zhao, R., Peng, H. Q., et al. (2008). Fatal parvoviral myocarditis: a case report and review of literature. Diagn. Pathol. 3, 1-6. doi: 10.1186/1746-1596-3-21

Thomas, S. A., Schuessler, R. B., Berul, C. I., Beardslee, M. A., Beyer, E. C., Mendelsohn, M. E., et al. (1998). Disparate effects of deficient expression of connexin 43 on atrial and ventricular conduction: evidence for chamberspecific molecular determinants of conduction. Circulation 97, 686-691. doi: 10.1161/01.CIR.97.7.686

Tomari, Y., and Zamore, P. D. (2005). Perspective: machines for RNAi. Genes Dev. 19, 517-529. doi: 10.1101/gad.1284105

Tominaga, M., Matsumori, A., Horie, M., Yoshida, H., and Okada, Y. (1993). Activation of Ca-permeable cation channels by myocarditis-associated 
antibody in guinea pig ventricular myocytes. J. Clin. Invest. 91, 1231-1234. doi: 10.1172/JCI116285

Tong, L., Lin, L., Wu, S., Guo, Z., Wang, T., Qin, Y., et al. (2013). MiR-10a* upregulates coxsackievirus $\mathrm{B} 3$ biosynthesis by targeting the $3 \mathrm{D}$-coding sequence. Nucleic Acids Res. 41, 3760-3771. doi: 10.1093/nar/gkt058

Tse, G. (2015). Mechanisms of Cardiac Arrhythmias. J. Arrhythm. 32, 75-81. doi: 10.1016/j.joa.2015.11.003

Tse, G. (2016a). Both transmural dispersion of repolarization and transmural dispersion of refractoriness are poor predictors of arrhythmogenicity: A role for the index of Cardiac Electrophysiological Balance (QT/QRS)? J. Geriatr. Cardiol.

Tse, G. (2016b). Novel conduction-repolarization indices for the stratification of arrhythmic risk. J. Geriatr. Cardiol.

Tse, G. (2016c). (Tpeak-Tend)/QRS and (Tpeak-Tend)/(QT $x$ QRS): novel markers for predicting arrhythmic risk in Brugada syndrome. Europace. doi: 10.17863/CAM.113

Tse, G., Ali, A., Alpendurada, F., Prasad, S., Raphael, C. E., and Vassiliou, V. (2015a). Tuberculous constrictive pericarditis. Res. Cardiovasc. Med. 4:e29614. doi: 10.5812/cardiovascmed.29614

Tse, G., Ali, A., Prasad, S. K., Vassiliou, V., and Raphael, C. E. (2015b). Atypical case of post-partum cardiomyopathy: an overlap syndrome with arrhythmogenic right ventricular cardiomyopathy? BJR Case Rep. 1, 20150182. doi:10.1259/bjrcr.20150182

Tse, G., Hothi, S. S., Grace, A. A., and Huang, C. L. (2012). Ventricular arrhythmogenesis following slowed conduction in heptanol-treated, Langendorff-perfused mouse hearts. J. Physiol. Sci. 62, 79-92. doi: 10.1007/s12576-011-0187-2

Tse, G., Lai, E. T., Lee, A. P., Yan, B. P., and Wong, S. H. (2016a). Electrophysiological mechanisms of gastrointestinal arrhythmogenesis: lessons from the heart. Front. Physiol. 7:230. doi: 10.3389/fphys.2016. 00230

Tse, G., Lai, E. T., Tse, V., and Yeo, J. M. (2016b). Molecular and electrophysiological mechanisms underlying cardiac arrhythmogenesis in diabetes mellitus. J. Diabetes Res.

Tse, G., Lai, E. T., Yeo, J. M., and Yan, B. P. (2016c). Electrophysiological mechanisms of Bayés syndrome: insights from clinical and mouse studies. Front. Physiol. 7:188. doi: 10.3389/fphys.2016.00188

Tse, G., Lai, T. H., Yeo, J. M., Tse, V., and Wong, S. H. (2016d). Mechanisms of electrical activation and conduction in the gastrointestinal system: lessons from cardiac electrophysiology. Front. Physiol. 7:182. doi: 10.3389/fphys.2016. 00182

Tse, G., Sun, B., Wong, S. T., Tse, V., and Yeo, J. M. (2016e). Ventricular antiarrhythmic effects of hypercalcaemia treatment in hyperkalaemic, Langendorffperfused mouse hearts. Biomed. Rep. doi: 10.3892/br.2016.577

Tse, G., Tse, V., and Yeo, J. M. (2016f). Ventricular anti-arrhythmic effects of heptanol in hypokalaemic, Langendorff-perfused mouse hearts. Biomed Rep. 4, 313-324. doi: 10.3892/br.2016.577

Tse, G., Tse, V., Yeo, J. M., and Sun, B. (2016g). Atrial anti-arrhythmic effects of heptanol in Langendorff-perfused mouse hearts. PLoS ONE. 11:e0148858. doi: 10.1371/journal.pone. 0148858

Tse, G., Wong, S. T., Tse, V., and Yeo, J. M. (2016h). Depolarization vs. repolarization: what is the mechanism of ventricular arrhythmogenesis underlying sodium channel haploinsufficiency in mouse hearts? Acta Physiol (Oxf). doi: 10.1111/apha.12694. [Epub ahead of print].

Tse, G., Wong, S. T., Tse, V., and Yeo, J. M. (2016i). Determination of action potential wavelength restitution in Scn $5 \mathrm{a}+/-$ mouse hearts modelling human Brugada syndrome. J. Physiol.

Tse, G., Wong, S. T., Tse, V., and Yeo, J. M. (2016j). Monophasic action potential recordings: which is the recording electrode? J. Basic Clin. Physiol. Pharmacol. doi: 10.1515/jbcpp-2016-0007. [Epub ahead of print].

Tse, G., Wong, S. T., Tse, V., and Yeo, J. M. (2016k). Restitution analysis of alternans using dynamic pacing and its comparison with S1S2 restitution in heptanol-treated, hypokalaemic Langendorff-perfused mouse hearts. Biomed. Rep. 4, 673-680. doi: 10.3892/br.2016.659

Tse, G., Wong, S. T., Tse, V., and Yeo, J. M. (2016l). Variability in local action potential durations, dispersion of repolarization and wavelength restitution in aged wild-type and Scn5a+/- mouse hearts modelling human Brugada syndrome. J. Geriatr. Cardiol.
Tse, G., Wong, S. T. T. V., Lee, Y. T., Lin, H. Y., and Yeo, J. M. (2016m). Cardiac dynamics: alternans and arrhythmogenesis. J. Arrhythm. doi: 10.1016/j.joa.2016.02.009

Tse, G., and Yan, B. P. (2016a). Novel arrhythmic risk markers incorporating QRS dispersion: QRSd x (Tpeak-Tend) / QRS and QRSd x (Tpeak-Tend) / (QT x QRS). Ann. Noninvasive Electrocardiol.

Tse, G., and Yan, B. P. (2016b). Traditional and novel electrocardiographic markers for predicting arrhythmic risk and sudden cardiac death. Europace.

Tse, G., Yan, B. P., Chan, Y. W., Tian, X. Y., and Huang, Y. (2016n). Reactive oxygen species, endoplasmic reticulum stress and mitochondrial dysfunction: the link with cardiac arrhythmogenesis. Front. Physiol. 7:313. doi: 10.3389/fphys.2016. 00313

Tse, G., and Yeo, J. M. (2015). Conduction abnormalities and ventricular arrhythmogenesis: the roles of sodium channels and gap junctions. Int. J. Cardiol. Heart Vasc. 9, 75-82. doi: 10.1016/j.ijcha.2015.10.003

Tse, G., Yeo, J. M., Tse, V., and Sun, B. (2016o). Gap junction inhibition by heptanol increases ventricular arrhythmogenicity by decreasing conduction velocity without affecting repolarization properties or myocardial refractoriness in Langendorff-perfused mouse hearts. Mol. Med. Rep.

Ukimura, A., Satomi, H., Ooi, Y., and Kanzaki, Y. (2012). Myocarditis associated with influenza A H1N1pdm2009. Influenza Res. Treat. 2012, 8. doi: $10.1155 / 2012 / 351979$

Vaidya, D., Morley, G. E., Samie, F. H., and Jalife, J. (1999). Reentry and fibrillation in the mouse heart. A challenge to the critical mass hypothesis. Circ. Res. 85, 174-181. doi: 10.1161/01.RES.85.2.174

Vaidya, D., Tamaddon, H. S., Lo, C. W., Taffet, S. M., Delmar, M., Morley, G. E., et al. (2001). Null mutation of connexin43 causes slow propagation of ventricular activation in the late stages of mouse embryonic development. Circ. Res. 88, 1196-1202. doi: 10.1161/hh1101.091107

Valdes, O., Acosta, B., Pinon, A., Savon, C., Goyenechea, A., Gonzalez, G., et al. (2008). First report on fatal myocarditis associated with adenovirus infection in Cuba. J. Med. Virol. 80, 1756-1761. doi: 10.1002/jmv.21274

van Rijen, H. V., Eckardt, D., Degen, J., Theis, M., Ott, T., Willecke, K., et al. (2004). Slow conduction and enhanced anisotropy increase the propensity for ventricular tachyarrhythmias in adult mice with induced deletion of connexin43. Circulation 109, 1048-1055. doi: 10.1161/01.CIR.0000117402.70689.75

Vassiliou, V., Chin, C., Perperoglou, A., Tse, G., Ali, A., Raphael, C., et al. (2014). 93 Ejection fraction by cardiovascular magnetic resonance predicts adverse outcomes post aortic valve replacement. Heart 100, A53-A54. doi: 10.1136/heartjnl-2014-306118.93

Veeraraghavan, R., Lin, J., Hoeker, G. S., Keener, J. P., Gourdie, R. G., and Poelzing, S. (2015). Sodium channels in the $\mathrm{Cx} 43$ gap junction perinexus may constitute a cardiac ephapse: an experimental and modeling study. Pflugers Arch. 467, 2093-2105. doi: 10.1007/s00424-014-1675-Z

Veeraraghavan, R., Poelzing, S., and Gourdie, R. G. (2014a). Intercellular electrical communication in the heart: a new, active role for the intercalated disk. Cell Commun. Adhes. 21, 161-167. doi: 10.3109/15419061.2014.905932

Veeraraghavan, R., Poelzing, S., and Gourdie, R. G. (2014b). Novel ligands for zipping and unzipping the intercalated disk: today's experimental tools, tomorrow's therapies? Cardiovasc. Res. 104, 229-230. doi: 10.1093/cvr/cvu216

Veeraraghavan, R., Poelzing, S., and Gourdie, R. G. (2014c). Old cogs, new tricks: a scaffolding role for connexin 43 and a junctional role for sodium channels? FEBS Lett. 588, 1244-1248. doi: 10.1016/j.febslet.2014.01.026

Veeraraghavan, R., Salama, M. E., and Poelzing, S. (2012). Interstitial volume modulates the conduction velocity-gap junction relationship. Am. J. Physiol. Heart Circ. Physiol. 302, H278-H286. doi: 10.1152/ajpheart.008 68.2011

Venkat Raman, G., Prosser, A., Spreadbury, P. L., Cockcroft, P. M., and Okubadejo, O. A. (1988). Rabies presenting with myocarditis and encephalitis. J. Infect. 17, 155-158. doi: 10.1016/S0163-4453(88)91767-7

Wakisaka, Y., Niwano, S., Niwano, H., Saito, J., Yoshida, T., Hirasawa, S., et al. (2004). Structural and electrical ventricular remodeling in rat acute myocarditis and subsequent heart failure. Cardiovasc. Res. 63, 689-699. doi: 10.1016/j.cardiores.2004.04.020

Woolf, P. K., Chung, T. S., Stewart, J., Lialios, M., Davidian, M., and Gewitz, M. H. (1987). Life-threatening dysrhythmias in varicella myocarditis. Clin. Pediatr. (Phila) 26, 480-482. doi: 10.1177/000992288702600911 
Xu, H. F., Ding, Y. J., Shen, Y. W., Xue, A. M., Xu, H. M., Luo, C. L., et al. (2012). MicroRNA- 1 represses Cx43 expression in viral myocarditis. Mol. Cell. Biochem. 362, 141-148. doi: 10.1007/s11010-011-1136-3

Ye, X., Hemida, M. G., Qiu, Y., Hanson, P. J., Zhang, H. M., and Yang, D. (2013). MiR-126 promotes coxsackievirus replication by mediating cross-talk of ERK1/2 and Wnt/beta-catenin signal pathways. Cell. Mol. Life Sci. 70, 4631-4644. doi: 10.1007/s00018-013-1411-4

Yoshikawa, T., Ihira, M., Suzuki, K., Suga, S., Kito, H., Iwasaki, T., et al. (2001). Fatal acute myocarditis in an infant with human herpesvirus 6 infection. J. Clin. Pathol. 54, 792-795. doi: 10.1136/jcp.54.10.792
Conflict of Interest Statement: The authors declare that the research was conducted in the absence of any commercial or financial relationships that could be construed as a potential conflict of interest.

Copyright (c) 2016 Tse, Yeo, Chan, Lai and Yan. This is an open-access article distributed under the terms of the Creative Commons Attribution License (CC BY). The use, distribution or reproduction in other forums is permitted, provided the original author(s) or licensor are credited and that the original publication in this journal is cited, in accordance with accepted academic practice. No use, distribution or reproduction is permitted which does not comply with these terms. 